\title{
Avoidance behavior in rats as a function of the slze and location of anterior cingulate cortex lesions'
}

CLINTON L. TRAFTON, ROBERT A. FILBEY, and REBECCA W. JOHNSON, University of Arizona, Tucson, Ariz. 85721

In 1967. Trafton found that lesions in the anterior midline cortex led to extreme deficits in conditioned avoidance response (CAR) learning in rats. The present study varied the placement and size of anterior cortical lesions in an attempt to further define the areas which are critical in producing the learning deficit. The results indicate a significant correlation between the size of the lesion and the degree of learning deficit in a shuttlebox. The placement of the lesion within the anterior cingulate area was not found to be associated with $C A R$ performance in any predictable manner.

There is some disagreement as to the cyto-architectonic subdivisions represented by various labels for anterior midline cortical tissue in rats. As parcellated by Kuhlenbeck, Szekely, \& Spuler (1960), the midline cortex extending caudally from the frontal pole to a region slightly posterior and dorsal to the genu of the corpus callosum is called anterior cingulate (or parahippocampal) cortex. Krieg (1946), on the other hand, describes the same tissue as consisting of anterior cingulate cortex (Area 24), subgenual cortex (Area 25), and pregenual cortex (Area 32). Figure 1 shows medial view drawings of the areas in question.

Trafton (1967) has raised a similar question with respect to the functional parcellation of this brain area. He found that lesions in the anterior midline cortex caused extreme deficits in both conditioned avoidance response (CAR) and conditioned emotional response (CER) learning. The lesions

(a)

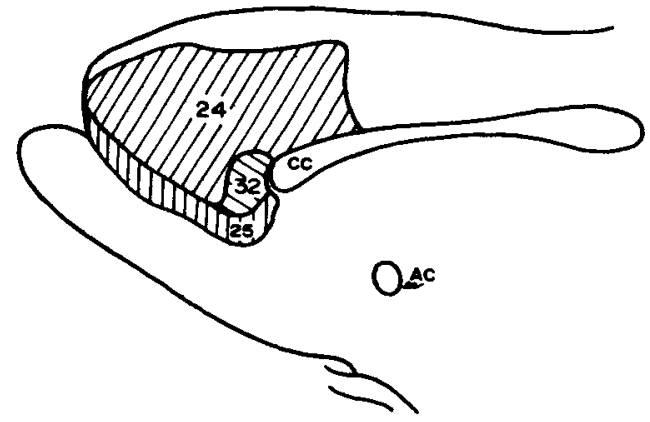

(b)

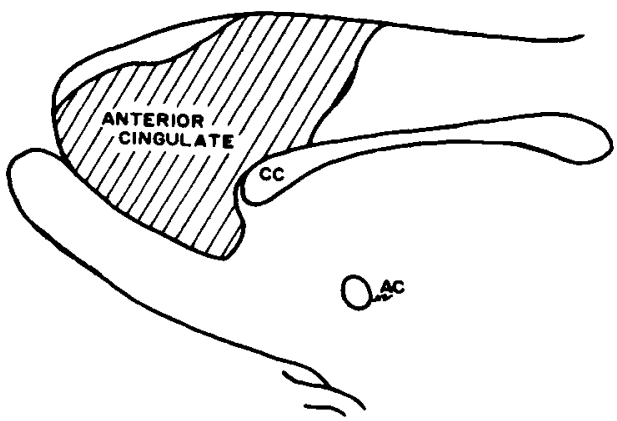

Fig. 1. Anterior midline cortex approximately as parcellated by (a) Krieg (1946) and (b) Kuhlenbeck et al (1960). cc: corpus callosum; AC: anterior commissure. typically involved all three areas labeled by Krieg $(24,25$, and 32 ) and Trafton speculated that damage to Area 32 might be critical in the learning deficits.

The present experiment was designed to further define which portion(s) of the anterior midline cortex must be destroyed to produce such CAR learning deficits.

\section{METHOD}

The Ss were female albino rats of the Holtzman strain. Group A $(N=8)$ was given bilateral electrolytic lesions in the anterior cingulate cortex (Krieg's Area 24); Group SP $(\mathrm{N}=5$ ) was given lesions in the subpregunual areas ( 32 and 25). Group ASP ( $N=6)$ was given lesions including all three areas $(24,25$, and 32$)$. A fourth group $(N=6)$ served as unlesioned controls. The lesions were made via stainless steel electrodes using direct current. A 1.5-mA current was delivered at each site and the larger lesions were made by moving the electrode to several adjacent target areas.

Behavior was evaluated in a double-grill box modeled after that used by Trafton (1967). Ss were given five trials per day for 30 days using a CS-UCS delay of $10 \mathrm{sec}$ and randomized intertrial intervals of $1 / 2,1,1 \frac{1}{2}, 2$, or $2 \frac{1}{2} \mathrm{~min}$. The CS was the onset of a $7 \frac{1}{2}-\mathrm{W}$ bulb which came on in the compartment opposite the one occupied by S. A UCS of $1.1 \mathrm{~mA} \mathrm{60-cycle} \mathrm{ac}$ was used. Ten days were allowed for recovery from surgery before CAR testing began.

Following CAR testing, the brains were recovered and sectioned through the lesion in the frontal plane at 30 microns and the sections were stained with cresylecht violet. Tracings were made of the lesions projected at $25 \mathrm{X}$ and an index of the volume of tissue destroyed was obtained for each $S$.

\section{RESULTS}

Of the three lesioned groups, the only group showing a significant deficit in CAR learning was Group ASP with combined lesions in both the anterior cingulate (Area 24) and subpregenual cortex areas (25 and 32). Figure 2 shows the course of CAR learning. Group ASP scored consistently and significantly lower in average number of CARs (Mann-Whitney $\mathrm{U}, \mathrm{p}<.05)$ than the control rats. Group ASP also took longer to respond, both on escape and avoidance trials, and were significantly slower ( $U$ test, $p<.05$ ) on escape trials. The

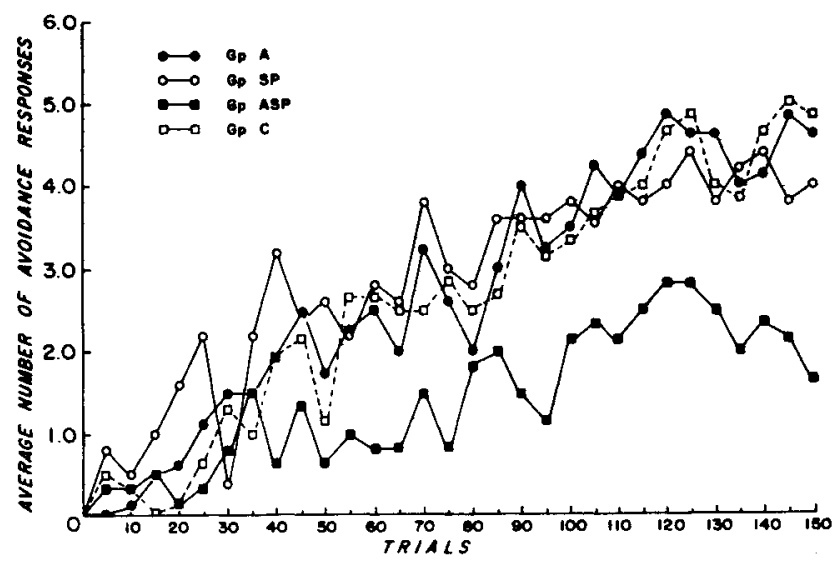

Fig. 2. Average number of CARs over 150 training triaks. Group $A$ : anterior cingulate lesion group; Group SP: subpregenual lesion group; Group ASP: combined anterior cingulate subpregenual lesion group; Group C: unlesioned control group. 


\section{DISCUSSION}

The results indicated that there were no significant performance differences in the acquisition data regardless of the presentation sequence of MP and saline conditions. The small increment in the response rate over the four acquisition sets can probably be attributed to the repeated presentation of acquisition-extinction conditions.

The extinction data indicated that only for the Group 1 sequence vs the Group 4 sequence were significant differences in the response rates present. These differences were limited to a significantly higher response rate by Group 1 Ss on the first day of the second set's extinction phase.

The failure of MP to produce a significant facilitation in performance in the present study may be the result of the control the schedule of reinforcement holds over the performance. The data do not support the positive findings on acquisition enhancement noticed in the avoidance paradigms. Such differences may be the result of MP effects specific to certain response topologies.

It is concluded that possible performance or retention enhancement effects of MP are not clearly evident in the present study, nor in many others, and that further experimentation is necessary.

\section{REFERENCES}

BEACH, G., \& KIMBLE, D. P. Activity and responsivity in rats after magnesium pemoline injections. Science, $1967,155,698$.

CHASE, T. C., \& RESCORLA, R. A. The effect of magnesium pemoline on learning an active avoidance-passive avoidance discrimination. Psychonomic Science, 1968, 10, 87-88.

CYERT, L. A., MOYER, K. E., \& CHAPMAN, J. A. Effect of magnesium pemoline on learning and memory of a one-way avoidance response.
Psychonomic Science, 1967, 7, 9-10.

FILBY, Y., SZARA, S., \& SALZMAN, B. Magnesium pemoline: Effect on acquisition and retention of discriminated avoidance behavior. Psy chonomic Science, 1967, 9, 131-132.

FILBY, Y., \& FRANK, L. Magnesium pemoline: Effects on drl performance. Psychonomic Science, 1968, 10, 265-266.

FREY, P. W., \& POLIDORA, V. J. Magnesium pemoline: Effect on avoidance conditioning in rats. Science, 1967, 155, 1281.

GLASKY, A. J., \& SIMON, L. N. Magnesium pemoline: Enhancement of brain RNA polymerases. Science, 1966, 151, 702 .

GROSSER, G. S., SPRINTHALL, R. C., \& SIROIS, L. Magnesium pemoline: Activation of extinction responding after continuous reinforcement. Psychological Reports, 1967, 21, 11-14.

GUROWITZ, E. M., LUBAR, J. F., AIN, B. R., GROSS, D. A Disruption of passive avoidance learning by magnesium pemoline. Psychonomic Science, 1967, 8, 19-20.

KULKARNI, A. S. Magnesium pemoline: Facilitation of instrumental avoidance learning. Psy chonomic Science, 1967, 9, 39-40.

LUBAR, J. F., BOITANO, J. J., GUROWITZ, E. M., \& AIN, B. R. Enhancement of performance in the Hebb-Williams maze by magnesium pemoline. Psychonomic Science, 1967, 7, 381-382.

PLOTNIKOFF, N. Magnesium pemoline: Enhancement of memory after electroconvulsive shock in rats. Life Sciences, 1966, 5, 1495.

POWELL, B. J., MARTIN, L. K., \& KAMANO, D. K. Magnesium pemoline: Effects of training vs testing of an avoidance response. Psychonomic Science, 1967a, 8, 205-206.

POWELL, B. J., MARTIN, L. K., \& KAMANO, D. K. More on magnesium pemoline: Differential effects of advance and immediate injections on avoidance performance. Psychonomic Science, 1967b, 8 , 303-304.

THOMPSON, R. W., \& KNUDSON, G. R. Magnesium pemoline: Facilitation of one way and two way avoidance learning. Psychonomic Science, 1968, 11, 155-156.

\section{NOTE}

1. The authors thank Dr. Hollis G. Schoepke and Abbott Laboratories for supplying the magnesium pemoline used in this study. control group averaged $3.2 \mathrm{sec}$ and $11.9 \mathrm{sec}$ on avoidance and escape trials, respectively, while Group ASP averaged $4.5 \mathrm{sec}$ and $13.6 \mathrm{sec}$. Groups A and SP were not significantly different from control Ss on any measure.

Histology revealed extensive lesions in the target areas and supported the behavioral results, indicating that lesion location within the anterior cingulate area was not related to CAR in any obvious manner. Figure 3 shows sagittal view drawings of the lesioned areas. The largest and smallest lesions in the various groups are shown. The lesions were fairly symmetrical bilaterally, and extended approximately $1.0 \mathrm{~mm}$ laterally from the midline. The extent of damage to the combined areas was negatively correlated $(p=-0.47, p<.05)$ with CAR performance for all three experimental groups. Only one $\mathrm{S}$ showed a lesion as extensive as those of Trafton's (1967) anterior cingulate lesion groups and that $S$ avoided only once in 150 trials. The difference in the degree of damage probably accounts for the partial learning of Group ASP whereas Trafton's Ss showed no evidence of CAR learning in 100 trials.

The results seem to indicate that, at least for CAR learning in a shuttle box, the areas lesioned in the present study are a functional unit, as indicated by Kuhlenbeck et al (1960). The cytoarchitectonic parcellation of Krieg (1946) does not appear to be related to CAR performance as measured by the present study.

\section{REFERENCES}

KRIEG, W. J. S. Connections of the cerebral cortex. I. The albino rat. A. Topography of the cortical areas. B. Structure of the cortical areas. Journal of Comparative Neurology, 1946, 84, 221-225, 277-323.

KUHLENBECK, H., SZEKELY, E. G., \& SPULER, H. Some remarks on the zonal pattern of mammalian cortex cerebri as manifested in the rabbit: Its relationship with certain electrocorticographic findings. Confinia Neurologica, 1960, 20, 407-423.
(A)

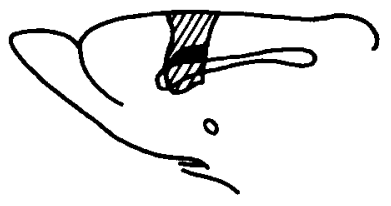

(SP)

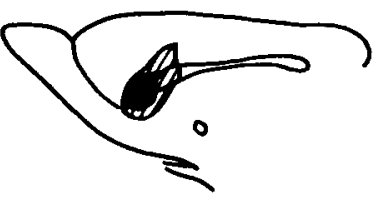

(ASP)

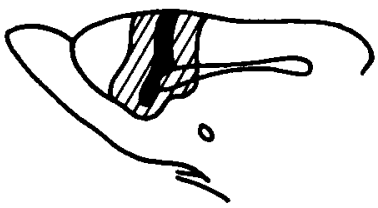

Fig. 3. Anterior midline cortex lesions for Groups A, SP, and ASP. The cross-hatched area represents the extent of the largest lesion, and the darkened area represents the extent of the smallest lesion in the group.

TRAFTON, C. L. Effects of lesions in the septal area and cingulate cortical areas on conditioned suppression of activity and avoidance behavior in rats. Journal of Comparative \& Physiological Psychology, 1967, 63, 191-197.

NOTE

1. This research was carried out at Pomona College, Claremont, California and was partially supported by a Ford Foundation grant. 